\title{
OPTIMIZATION OF CULTURAL CONDITIONS FOR LACTIC ACID PRODUCTION BY LACTOBACILLUS BULGARICUS ATTC 11842 GROWN ON WHEY
}

\author{
M. Kitouni ${ }^{1}$, L. Oulmi ${ }^{2}$ \\ ${ }^{1,2}$ Laboratory of applied biology and health, Faculty of natural sciences and life, University Constantine 1, Ain El Bey \\ street 25000, Constantine, ALGERIA, mahmoudkitouni@yahoo.fr
}

\begin{abstract}
The effects on the lactic acid (LA) production by thermophile Lactobacillus bulgaricus ATTC 11842 on whey as a basal medium of seven factors namely, temperature ${ }^{\circ} \mathrm{C}, \mathrm{pH}$, Lactose g/l, Yeast extract g/l, corn steep liquor (CSL) g/l, $\mathrm{K}_{2} \mathrm{HPO}_{4} \mathrm{~g} / \mathrm{l}$, and salts g/l $\left(\mathrm{MnSO}_{4}, \mathrm{MgSO}_{4}\right.$ and $\left.\mathrm{FeSO}_{4}\right)$ were investigated, through the statistical analysis of the results by Plackett and Burmann experimental design. $\mathrm{pH}$ was found to have the high significant effect on lactic acid production. By response surface methodology (RSM) design the optimal value of $\mathrm{pH}$ and concentrations in the medium of yeast extract, $\mathrm{K}_{2} \mathrm{HPO}_{4}$ and salts were then investigated, it should be 5.5 of $\mathrm{pH}, 2.73 \mathrm{~g} / \mathrm{l}$ of $\mathrm{K}_{2} \mathrm{HPO}_{4}, 1.59 \mathrm{~g} / \mathrm{l}$ of yeast extract and $0.0326 \mathrm{~g} / \mathrm{l}, 0.1304 \mathrm{~g} / \mathrm{l}, 0.01304 \mathrm{~g} / \mathrm{l}$ of $\mathrm{MgSO}_{4}, \mathrm{MnSO}_{4}$ and $\mathrm{FeSO}_{4}$ respectively. The results obtained with the optimal results were $20.9592 \mathrm{~g} / \mathrm{l}$. of lactic acid and the corresponding yields was $0.5665 \%$ (ratio between the amount of lactic acid produced and the initial concentration of lactose).
\end{abstract}

Index Terms: Lactic acid, experimental design, Plackett and Burmann, Lactobacillus bulgaricus, whey

\section{INTRODUCTION}

Lactic acid is a natural organic acid, which has many applications in pharmaceutical, food and chemical industries. These include: uses as an acidulant, preservative and in recent years as a substrate for the production of biodegradable plastics. These plastics besides its application in food and cosmetic industry [19] are applied as drug-carriers [13] and for biodegradable packaging [11].

Lactic acid is produced by chemical synthesis and microbial fermentation. Chemical synthesis results in racemic mixture of lactic acid whereas specific stereo isomeric form can be obtained by microbial fermentation [15]. The fermentative production of lactic acid is interesting due to the prospect of using cheap raw materials. The most attractive method for lactic acid production is fermentation of lactose in whey, a typical $\mathrm{e} \square$ uent from dairies. Hence, two problems could be solved at the same time wastewater treatment due to its high biochemical oxygen demand (BOD) 30000-50000 ppm [18] and useful product recovery. There are many reports on the lactic acid fermentation potential of Lactobacillus bacteria using lactose as substrate $[9,23]$.

Lactic acid production from various substrates like corn [21], sugarcane [5], cassava [22], beets [12], paper sludge [14], biodiesel [3] and green microalga, Hydrodictyon reticulum [16] has been studied to meet the increasing demands for lactic acid. In this article, lactic acid production from whey using Lactobacillus bulgaricus (ATCC 11842) has been studied. The optimal conditions for the production of lactic acid were determined in flask culture.

\section{MATERIALS AND MEDTHODS}

\subsection{Microorganism}

The lactic acid bacterium used was Lactobacillus bulgaricus (ATCC 11842). The strain was stored in De Man, Rogosa and Sharpe (MRS) broth with $20 \%$ (v/v) glycerol at $18^{\circ} \mathrm{C}$.

\section{2 Media and Culture Conditions}

Cheese whey containing $52 \%$ (w/v) lactose was obtained from Boudouaou ONALAIT Algiers. Deproteinization was carried out by heat treatment $\left(100^{\circ} \mathrm{C}\right.$ for $\left.10 \mathrm{~min}\right)$ Then adjusted to $\mathrm{pH}=4.6$ (isoelectric point of protein flocculation) by adding to whey $10 \mathrm{M} \mathrm{HCl}$ solution and cooled at room temperature. The resulting whey solution was centrifuged at $10000 \mathrm{~g}$ to remove the solids and the supernatant was diluted to reach the desired lactose concentration. The inoculum was prepared by transferring glycerol stock culture $(1 \mathrm{ml})$ to an Erlenmeyer flask containing $100 \mathrm{ml}$ of MRS medium and incubated at $46^{\circ} \mathrm{C}$ for $18 \mathrm{~h}$ on a rotary shaker at $200 \mathrm{rpm}$. Experiments were performed in $250 \mathrm{ml}$ Erlenmeyer flasks containing $50 \mathrm{ml}$ of production medium inoculated with $10 \%$ inoculum grown in the MRS medium. The flasks were then incubated on a rotary shaker at $200 \mathrm{rpm}$ and at the desired 
temperature according to experimental design. To avoid $\mathrm{pH}$ decrease due to lactic acid production, $50 \mathrm{~g} / \mathrm{l}$ of sterile $\mathrm{CaCO}_{3}$ in powder form was added to each flask [10].

\subsection{Experimental Design and Statistical Analysis}

To select the factors that affect the lactic acid production we chose the Plackett-Burmann experimental design. It allows the study of $\mathrm{k}$ variables with $\mathrm{k}+1$ experiment. The experimental design applied to this study is presented in Table 1. The columns represent different variables and the rows represent different experiments. To estimate the experimental error four variables (X3, X6, X9 and X11) are designed as dummy variables. In each case a high and a low level of each variable (nutrient, $\mathrm{pH}$ ) were tested. The Plakett-Burman design assumes that there are no interactions between the different media constituents, $\mathrm{Xi}$ in the range of variables (factors) under consideration [17]. A linear approach is considered to be sufficient for screening. $Y=\beta_{0}+\sum \beta \mathrm{iXi}(\mathrm{i}=1 \ldots \ldots \mathrm{k})$ where $\mathrm{Y}$ is the experimental response, $\beta_{0}$ the main effects of the factors, $\beta_{\mathrm{i}}$ are the regression coefficients. The Plackett-Burman experimental design is a fractional factorial design and the main effect of such a design may be simply calculated as the difference between the average of measurements made at the high level (+1) of the factor and the average of measurements at the low level $(-1)$. All experiments were carried out in duplicate. Identification of factors and their concentrations are shown in Table 2 . The first order polynomial coefficients were calculated and analyzed using the ' $\mathrm{R}$ ' software (version 2.14.1 (2011-12-22) statistical package. Statistical analysis of the model was performed to evaluate the analysis of variance (ANOVA).

Table 1 twelve trials Plackett-Burman Design with the responses (lactic acid production $\mathrm{g} / \mathrm{l}$ )

\begin{tabular}{|c|c|c|c|c|c|c|c|c|c|c|c|c|}
\hline \multirow[b]{2}{*}{ Run } & \multicolumn{11}{|c|}{ Factors } & \multirow{2}{*}{ 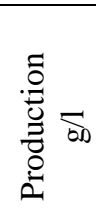 } \\
\hline & $\bar{x}$ & $\tilde{x}$ & $\tilde{x}$ & $\ddot{x}$ & $x$ & $\ddot{x}$ & $\bar{x}$ & $\stackrel{\infty}{x}$ & 2 & $\frac{0}{x}$ & $\bar{x}$ & \\
\hline 01 & + & + & - & + & + & + & - & - & - & + & - & 17.89 \\
\hline 02 & - & + & + & - & + & + & + & - & - & - & + & 12.45 \\
\hline 03 & + & - & + & + & - & + & + & + & - & - & - & 3.11 \\
\hline 04 & - & + & - & + & + & - & + & + & + & - & - & 20.18 \\
\hline 05 & - & - & + & - & + & + & - & + & + & + & - & 6.22 \\
\hline 06 & - & - & - & + & - & + & + & - & + & + & + & 5.51 \\
\hline 07 & + & - & - & - & + & - & + & + & - & + & + & 2.73 \\
\hline 08 & + & + & - & - & - & + & - & + & + & - & + & 8.48 \\
\hline 09 & + & + & + & - & - & - & + & - & + & + & - & 17.36 \\
\hline 10 & - & + & + & + & - & - & - & + & - & + & + & 12.62 \\
\hline 11 & + & - & + & + & + & - & - & - & + & - & + & 8.71 \\
\hline 12 & - & - & - & - & - & - & - & - & - & - & - & 3.73 \\
\hline
\end{tabular}

+: Higher level; -: Lower level The four factors X 3 , X 6 , X 9 , and X 11 are designated as "dummy factors".

Table 2 Relationship between the coded levels and the actual levels of the used 11 factors

\begin{tabular}{|c|c|c|}
\hline \multirow{2}{*}{ Factors } & \multicolumn{2}{|c|}{ Levels } \\
\hline & - & + \\
\hline $\mathrm{X} 1:$ Temperatur ${ }^{\circ} \mathrm{C}$ & 45 & 48 \\
\hline $\mathrm{X} 2: \mathrm{pH}$ & 5 & 6 \\
\hline X3 : Dummy 1 & - & - \\
\hline $\mathrm{X} 4:$ Lactose $\mathrm{g} / \mathrm{l}$ & 26 & 37 \\
\hline X5 : Yeast extract $\mathrm{g} / \mathrm{l}$ & 0 & 2 \\
\hline X6 : Dummy 2 & - & - \\
\hline $\mathrm{X} 7: \mathrm{K}_{2} \mathrm{HPO}_{4} \mathrm{~g} / \mathrm{l}$ & 0 & 5 \\
\hline X8 : Cornsteep g/l & 0 & 2 \\
\hline X9: Dummy 3 & - & - \\
\hline X10 : Salts g/l : & & \\
\hline $\mathrm{MnSO}_{4}$ & 0 & 0.5 \\
\hline $\mathrm{MgSO}_{4}$ & 0 & 2 \\
\hline $\mathrm{FeSO}_{4}$ & 0 & 0.2 \\
\hline X11: Dummy 4 & - & - \\
\hline
\end{tabular}

To optimize $\mathrm{pH}$, phosphate, salts and yeast extract for lactic acid production a central composite design was used. It allows us to study each factor at five different levels [4]. It is composed of three distinct parts: 16 points with coordinates ($1,+1)$, which forms a full factorial design, 8 star points with levels -2 and +2 and 4 repetitions of the central point (level 0 ). In this study, the value of the dependent response (lactic acid production) was the averages of duplicate experiments. Experimental conditions are mentioned in Tables 3, 4.

The second order polynomial coefficients were calculated and analyzed using the ' $R$ ' software (version 2.14.1 (2011-12-22) statistical package. Statistical analysis of the model was performed to evaluate the analysis of variance (ANOVA). Response surfaces (3D plots) were drawn for experimental results obtained from the interactive effects of the independent variables on the lactic acid production.

Table 3 Experimental range and levels of the independent variables $\mathrm{X} 1-\mathrm{X} 4$ used in central composite design

\begin{tabular}{|c|c|c|c|c|c|}
\hline \multirow{2}{*}{ Factor } & \multicolumn{5}{|c|}{ Level } \\
\hline & $-\alpha(-2)$ & -1 & 0 & 1 & $+\alpha(+2)$ \\
\hline $\begin{array}{c}\mathrm{X} 1: \mathrm{K}_{2} \mathrm{HPO}_{4} \\
(\mathrm{~g} / \mathrm{l})\end{array}$ & 0.5 & 1.5 & 2.5 & 3.5 & 4.5 \\
\hline $\mathrm{X} 2$ : Salts $(\mathrm{g} / \mathrm{l})$ : & & & & & \\
\hline $\mathrm{MnSO}_{4}$ & 0.025 & 0.075 & 0.125 & 0.175 & 0.225 \\
\hline $\mathrm{MgSO}_{4}$ & 0.1 & 0.3 & 0.5 & 0.7 & 0.9 \\
\hline $\mathrm{FeSO}_{4}$ & 0.01 & 0.03 & 0.05 & 0.07 & 0.09 \\
\hline $\mathrm{X} 3: \mathrm{pH}$ & 5.2 & 5.350 & 5.5 & 5.650 & 5.8 \\
\hline $\begin{array}{l}\text { X4 : Yeast } \\
\text { extract }(\mathrm{g} / \mathrm{l})\end{array}$ & 1 & 1.25 & 1.5 & 1.75 & 2 \\
\hline
\end{tabular}


Table 4 Central composite design for optimization of three variables (each on five levels) for the production of D-lactic acid by isolated Lactobacillus bulgaricus ATTC

\begin{tabular}{|c|c|c|c|c|c|}
\hline \multirow[b]{2}{*}{ Run } & \multicolumn{4}{|c|}{ Factors } & \multirow[b]{2}{*}{ 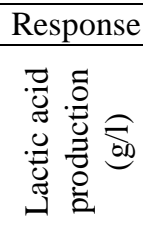 } \\
\hline & 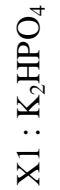 & $\begin{array}{l}\frac{a}{0} \\
\tilde{\omega} \\
\ddot{x}\end{array}$ & $\begin{array}{l}\frac{\pi}{2} \\
\ddot{2} \\
\ddot{x}\end{array}$ & 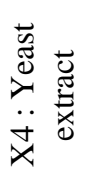 & \\
\hline 1 & -1 & -1 & -1 & -1 & 25.612 \\
\hline 2 & 1 & -1 & -1 & -1 & 25.944 \\
\hline 3 & -1 & 1 & -1 & -1 & 19.694 \\
\hline 4 & 1 & 1 & -1 & -1 & 22.321 \\
\hline 5 & -1 & -1 & 1 & -1 & 28.887 \\
\hline 6 & 1 & -1 & 1 & -1 & 25.486 \\
\hline 7 & -1 & 1 & 1 & -1 & 12.59 \\
\hline 8 & 1 & 1 & 1 & -1 & 25.454 \\
\hline 9 & -1 & -1 & -1 & 1 & 28.16 \\
\hline 10 & 1 & -1 & -1 & 1 & 29.394 \\
\hline 11 & -1 & 1 & -1 & 1 & 22.558 \\
\hline 12 & 1 & 1 & -1 & 1 & 15.311 \\
\hline 13 & -1 & -1 & 1 & 1 & 20.723 \\
\hline 14 & 1 & -1 & 1 & 1 & 28.872 \\
\hline 15 & -1 & 1 & 1 & 1 & 26.103 \\
\hline 16 & 1 & 1 & 1 & 1 & 27.242 \\
\hline 17 & -2 & 0 & 0 & 0 & 7.796 \\
\hline 18 & 2 & 0 & 0 & 0 & 9.758 \\
\hline 19 & 0 & -2 & 0 & 0 & 11.039 \\
\hline 20 & 0 & 2 & 0 & 0 & 7.479 \\
\hline 21 & 0 & 0 & -2 & 0 & 15.201 \\
\hline 22 & 0 & 0 & 2 & 0 & 29.679 \\
\hline 23 & 0 & 0 & 0 & -2 & 15.802 \\
\hline 24 & 0 & 0 & 0 & 2 & 15.486 \\
\hline 25 & 0 & 0 & 0 & 0 & 17.21 \\
\hline 26 & 0 & 0 & 0 & 0 & 18.508 \\
\hline 27 & 0 & 0 & 0 & 0 & 16.878 \\
\hline 28 & 0 & 0 & 0 & 0 & 18.65 \\
\hline
\end{tabular}

The optimized conditions generated during response surface methodology implementation were validated by conducting experiment on given optimal medium setting. Three runs were carried out in triplicate to confirm the results.

\section{4 Analytical methods}

Lactose and lactic acid concentration in the supernatant were determined spectrophotometrically by the phenol-sulphuric acid method [8] and $\mathrm{Fe}^{3+}$.lactate complex methode [2] respectively.

\section{RESULTS AND DISCUSSION}

\subsection{Selection of variables}

The results obtained after fermentation flasks are expressed in $\mathrm{g} / \mathrm{l}$ for the amount of lactic acid produced and mentioned in table 2. Statistical Treatment was made using a program $\mathrm{R}$ package and the results are shown in (Table 5).

Table 5 The effects of the explicative factors on the production of lactic acid

\begin{tabular}{|c|c|c|c|}
\hline Factors & 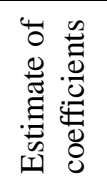 & 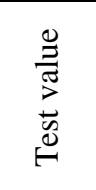 & 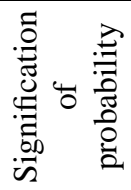 \\
\hline X1 : Temperatur & -0.406 & 0.191 & - \\
\hline $\mathrm{X} 2: \mathrm{pH}$ & 9.826 & 4.6 & $95 \%$ \\
\hline X3 : Dummy 1 & 0.322 & 0.151 & - \\
\hline X4 : Lactose & 2.841 & 1.330 & $70 \%$ \\
\hline X5 : Yeast extract & 2.896 & 1.356 & $70 \%$ \\
\hline X6 : Dummy 2 & -1.946 & 0.911 & - \\
\hline $\mathrm{X} 7: \mathrm{K}_{2} \mathrm{HPO}_{4}$ & 0.617 & 0.289 & - \\
\hline X8 : Cornsteep & -2.052 & 0.961 & - \\
\hline X9 : Dummy 3 & 2.321 & 1.086 & - \\
\hline X10 : Salts & 0.944 & 0.442 & - \\
\hline X11: Dummy 4 & -2.996 & 1.403 & $70 \%$ \\
\hline
\end{tabular}

The signification column represents the acceptance probability of the factor to be selected.

Average $=9.91$, variance $=4.56$, degrees of freedom $=4$.

For a minimal probability of significance $70 \%$ all variables with a probability lower than $70 \%$ are rejected and considered without effect on the response (the production of lactic acid) Table 5 indicate that: Within the range of this study, temperature have not effect on the lactic acid production, the same result was obtained by Tuli et al. [20].

The variation of the $\mathrm{pH}$ of 5 to 6 causes an increase in the lactic acid production of $9.83 \mathrm{~g} / \mathrm{l}$. The strong effect of $\mathrm{pH}$ on the production of lactic acid and the efficiency of the strain indicates that we are near to the optimum value of $\mathrm{pH}$ which would be between 5.5 and 5.9 according to results obtained by Cristian et al. [7].

The increase in the amount of lactose $26 \mathrm{~g} / 1$ (diluted whey) to $36 \mathrm{~g} / \mathrm{l}$ (raw whey) increases the production of lactic acid of $2.84 \mathrm{~g} / \mathrm{l}$, this leads to the conclusion that the amount of lactose 
present in the undiluted whey is far to cause a substrate inhibition.

The presence of yeast extract increases the production of lactic acid with a value of $2.9 \mathrm{~g} / \mathrm{l}$ this result has already obtained by Aeschlimann and von Stockar [1]. The presence of corn-steep has no effect on the lactic acid production these results allow us to conclude that yeast extract was the best nitrogen source and growth factors compared to cornsteep, which corroborates the results reported by CHIARINI et al. [6]. The use of manganese, magnesium and iron sulfates as sources of oligoelements serving as cofactors of enzymes involved in the lactic acid fermentation [20] and $\mathrm{K}_{2} \mathrm{HPO}_{4}$ as a source of phosphate appears to have no significant effect on the response (lactic acid production).

One dummy in the case of lactic acid production have significant effect. Normally if there is no interaction between the studied variables, or errors in the measurement of the response (production of lactic acid), The effects of dummy are equal to zero, the values found can be explained by the fact that the matrices experience of Plackett and Burman experience and view the high order of fractionation effects are confounded with simple interaction of second order or more so the dummy can be confused with a significant interaction effect or dummy are due to truly errors measurements or assays performed.

The mean dummy is 0.575 for the production of lactic acid with insignificant $\mathrm{T}$ values (0.269). The results are therefore acceptable, which is confirmed by the percent effects compared to the average which shows that the effects of the factors are real and not just mathematical. For example, the $\mathrm{pH}$ affect with $99 \%$ lactic acid production so we can say that the $\mathrm{pH}$ plays an important role in this fermentation.

These results allow us to represent the response (the production of lactic acid) by the first degree polynomial equation.

$$
Y=\beta_{0}+\beta_{1} X_{1}+\beta_{2} X_{2}+\beta_{3} X_{3}+\beta_{4} X_{4}+\beta_{5} X_{5}+\beta_{6} X_{6}+\beta_{7} X_{7}+\varepsilon
$$

Where $\mathrm{Y}$ represents the experimental response (lactic acid production), $\beta_{0}$ the main effects of the factors, $\beta_{\mathrm{i}}$ are the regression coefficients and $\varepsilon$ represents the average of the experimental errors. The resulting equation for lactic acid production is:

$$
\begin{gathered}
Y=9.914-0.406 X_{1}+9.826 X_{2}+2.841 X_{3}+2.896 X_{4}+ \\
0.617 X_{5}+2.321 X_{6}+0.944 X_{7}+0.575
\end{gathered}
$$

So to get a good production of lactic acid it is appropriate to use:

a temperaure of incubation $46^{\circ} \mathrm{C}$;

a $\mathrm{pH}$ between 5.5 and 6;

yeast extract; low concentrations of salts and phosphate;

Raw whey.

It should be noted that to determine exactly the optima of the selected factors we should at least use a quadratic model.

\subsection{Determination of optimal conditions of $\mathrm{pH}$,}

\section{phosphate, salts and yeast extract}

Experimental conditions and results of fermentations in Erlenmeyer flasks are mentioned in the table 4. Statistical treatment was made by using statistical software $(\mathrm{R})$ and the results are shown in tables 6 and 7 .

High values of the correlation coefficient $\mathrm{R}(0.969)$ and the coefficient of determination $\mathrm{R}^{2}(0.940)$ shows that the chosen model is representative of our system (lactic acid production). The coefficient of determination $\left(\mathrm{R}^{2}\right)$ was 0.940 , indicating that $94 \%$ of the variability in the response lactic acid production could be explained by the model. In the following polynom:

$$
\begin{gathered}
(\operatorname{Pr})=\beta_{0}+\beta_{1} X_{1}+\beta_{2} X_{2}+\beta_{3} X_{3}+\beta_{4} X_{4}+\beta_{11} X_{1}^{2}+\beta_{22} X_{2}^{2}+ \\
\beta_{33} X_{3}^{2}+\beta_{44} X_{4}^{2}+\beta_{12} X_{1} X_{2}+\beta_{13} X_{1} X_{3}+\beta_{14} X_{1} X_{4}+\beta_{23} X_{2} X_{3} \\
+\beta_{24} X_{2} X_{4}+\beta_{34} X_{3} X_{4}
\end{gathered}
$$

The regressors are denoted $\mathrm{X}_{1}, \mathrm{X}_{2}, \mathrm{X}_{3}$ and $\mathrm{X}_{4}$, the hypothesis $\mathrm{H}_{0}$ is rejected, at least one of the coefficients is significantly different from zero. We can then use the estimated values of the coefficients to write that the best model for lactic acid production is:

$$
\begin{gathered}
\operatorname{Pr}=17.811+0.818 \mathrm{X}_{1}-2.039 \mathrm{X}_{2}+1.472 \mathrm{X}_{3}+0.489 \mathrm{X}_{4}- \\
0.593 \mathrm{X}_{1}^{2}-0.473 \mathrm{X}_{2}^{2}+2.822 \mathrm{X}_{3}^{2}+1.123 \mathrm{X}_{4}^{2}+0.192 \mathrm{X}_{1} \mathrm{X}_{2}+ \\
1.363 \mathrm{X}_{1} \mathrm{X}_{3}-0.572 \mathrm{X}_{1} \mathrm{X}_{4}+1.04 \mathrm{X}_{2} \mathrm{X}_{3}+0.621 \mathrm{X}_{2} \mathrm{X}_{4}+0.542 \\
\mathrm{X}_{3} \mathrm{X}_{4}
\end{gathered}
$$

As illustrated in Table 7, the insignificant lack-of-fit for all investigated variables shows that the polynomial models were satisfactorily accurate for predicting the relevant responses.

Table 6 Model coefficient estimated by linear regression

\begin{tabular}{|c|c|c|c|c|}
\hline \multirow{2}{*}{ Regressors } & \multicolumn{4}{|c|}{ Production of lactic acid } \\
\cline { 2 - 5 } & Estimate & Std. Error & $\mathrm{t}$ value & $\operatorname{Pr}(>|\mathrm{t}|)$ \\
\hline Intercept & 17.81150 & 3.84883 & 4.6278 & $0.0004732 * * *$ \\
\hline$\beta 1$ & 0.81754 & 1.57128 & 0.5203 & 0.6115990 \\
\hline$\beta 2$ & -2.03854 & 1.57128 & -1.2974 & 0.2170528 \\
\hline$\beta 3$ & 1.47163 & 1.57128 & 0.9366 & 0.3660498 \\
\hline$\beta 4$ & 0.48929 & 1.57128 & 0.3114 & 0.7604363 \\
\hline$\beta 12$ & 0.19181 & 1.92442 & 0.0997 & 0.9221245 \\
\hline$\beta 13$ & 1.36281 & 1.92442 & 0.7082 & 0.4913434 \\
\hline$\beta 14$ & -0.57169 & 1.92442 & -0.2971 & 0.7711062 \\
\hline
\end{tabular}




\begin{tabular}{|c|c|c|c|c|}
\hline$\beta 23$ & 1.04044 & 1.92442 & 0.5407 & 0.5978901 \\
\hline$\beta 24$ & 0.62094 & 1.92442 & 0.3227 & 0.7520813 \\
\hline$\beta 34$ & 0.54194 & 1.92442 & 0.2816 & 0.7826744 \\
\hline$\beta 1^{\wedge} 2$ & -0.59330 & 1.57128 & -0.3776 & 0.7118268 \\
\hline$X 2^{\wedge} 2$ & -0.47280 & 1.57128 & -0.3009 & 0.7682473 \\
\hline$X 3^{\wedge} 2$ & 2.82245 & 1.57128 & 1.7963 & 0.0957150 \\
\hline$X 4^{\wedge} 2$ & 1.12345 & 1.57128 & 0.7150 & 0.4872582 \\
\hline
\end{tabular}

\section{DEP VAR : Pr $\quad$ N : 28 Multiple R : 0.969}

Squared Multiple R : 0.940 Adjusted Squared Multiple R : 0.875 Standard error of estimate : $\mathbf{7 . 6 9 8}$

Table 7 Analysis of variance (ANOVA) for full quadratic model

\begin{tabular}{|c|c|c|c|c|c|}
\hline & \multicolumn{5}{|c|}{ Response : Production of lactic acid } \\
\hline Source & Df & $\begin{array}{c}\text { Sum } \\
\text { Sq }\end{array}$ & Mean Sq & F value & $\operatorname{Pr}(>\mathrm{F})$ \\
\hline $\begin{array}{c}\text { FO(X1, } \\
\text { X2, X3, } \\
\text { X4) }\end{array}$ & 4 & $\begin{array}{c}173.5 \\
0\end{array}$ & 43.375 & 0.7320 & 0.586123 \\
\hline $\begin{array}{c}\text { TWI(X1, } \\
\text { X2, X3, } \\
\text { X4) }\end{array}$ & 6 & 63.72 & 10.620 & 0.1792 & 0.977666 \\
\hline $\begin{array}{c}\text { PQ(X1, } \\
\text { X2, X3, } \\
\text { X4) }\end{array}$ & 4 & $\begin{array}{c}275.8 \\
1\end{array}$ & 68.953 & 1.1637 & 0.371195 \\
\hline $\begin{array}{c}\text { Residuals } \\
\text { Lack of fit }\end{array}$ & 13 & $\begin{array}{c}770.3 \\
0\end{array}$ & 59.254 & & \\
\hline Pure error & 3 & 2.42 & 0.807 & & 0.001578 \\
\hline
\end{tabular}

The 3D response surfaces are the graphical representations of the regression equation for lactic acid production. It is plotted to understand the interaction of the variables and locate the optimal level of each variable for maximal response. Each response surface plotted for lactic acid production represents the different combinations of two test variables at one time while maintaining the other variable at the zero level or stationary point. The convex response surfaces suggest that there are well defined optimal variables. If the surfaces are rather symmetrical and flat near the optimum, the optimized values may not vary widely from the single variable conditions. Figs. 1-6 show the effect of interaction respectively of $\mathrm{K}_{2} \mathrm{HPO}_{4}$ and Salts, $\mathrm{pH}$ and Yeast extract, $\mathrm{K}_{2} \mathrm{HPO}_{4}$ and $\mathrm{pH}, \mathrm{K}_{2} \mathrm{HPO}_{4}$ and Yeast extract, Salts and $\mathrm{pH}$, and Salts and Yeast extract on lactic acid production. From these plots, it is very easy and convenient to understand the interactions between two parameters and also to locate their optimum levels.
Figures 1 and 2 show that there is a strong interaction between the X1 $\left(\mathrm{K}_{2} \mathrm{HPO}_{4}\right)$ and $\mathrm{X} 2$ (salts) and on the other hand between $\mathrm{X} 3(\mathrm{pH})$ and $\mathrm{X} 4$ (Yeast extract). The shape of the response surfaces of Figure 3 and 4 show that there is no interaction of $\mathrm{K} 2 \mathrm{HPO} 4$ with both the $\mathrm{pH}$ as with yeast extract. Figures 5 and 6 indicate that there is either any interaction between the salts and $\mathrm{pH}$ and salts and yeast extract on the other hand. Lactic acid production was between 19 and $20 \mathrm{~g} / 1$ at the stationary point from the codified variables X1 (0.214), X2 (-1.879), X3 (-0.0004) and X4 (0.356). These values were confirmed by the determination of the stationary point of the equation $(\mathrm{Pr})$.

In Figure 3, we can see that $34 \mathrm{~g} / \mathrm{l}$ lactic acid is the maximum value obtained when the concentration of $\mathrm{K}_{2} \mathrm{HPO}_{4}$ and the $\mathrm{pH}$ are at their higher level (2) or lower (-2). The lactic acid production decreases when $\mathrm{pH}$ values tend to level 0 .

The lactic acid production is at its maximum level $(26 \mathrm{~g} / \mathrm{l})$, when the concentration of $\mathrm{K}_{2} \mathrm{HPO}_{4}$ is at its upper level (2), and the concentration of yeast extract is at its lower level $(-2)$. The lactic acid production is at its minimum level when the concentration of $\mathrm{K}_{2} \mathrm{HPO}_{4}$ is at its level -2 and the concentration of yeast extract is at level 0 . When the concentrations of the yeast extract tend to 0 , the lactic acid production decreases fig. 4 .

Maximum production of lactic acid is reached when the $\mathrm{pH}$ is at its highest level (2) whatever the level of factor X2 (salts). The minimum level of production is obtained when the salt concentration is at its level 2 , and the $\mathrm{pH}$ is between $(0$ and -1$)$ Fig. 5.

In Figure 6 we can see that when the concentration of salts and yeast extract are to their -2 levels, the production of lactic acid is at its maximum state. Production is at a minimum state when the salt concentration is at its level 2, and that of the yeast extract between 0 and -1 .

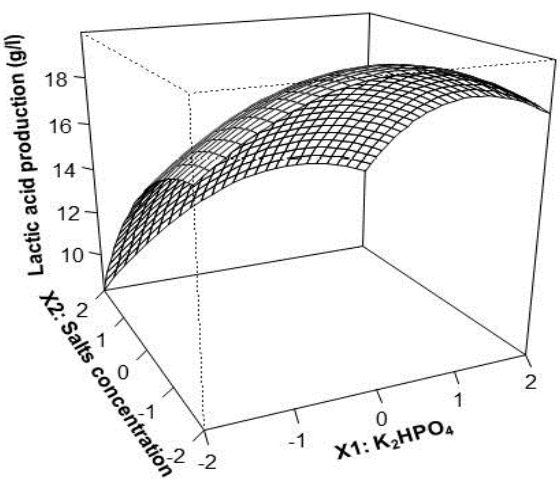

Fig -1: Effects of $\mathrm{K}_{2} \mathrm{HPO}_{4}$ and salts concentration and their mutual interactions on lactic acid production by $L b$. bulgaricus ATCC 11842. 


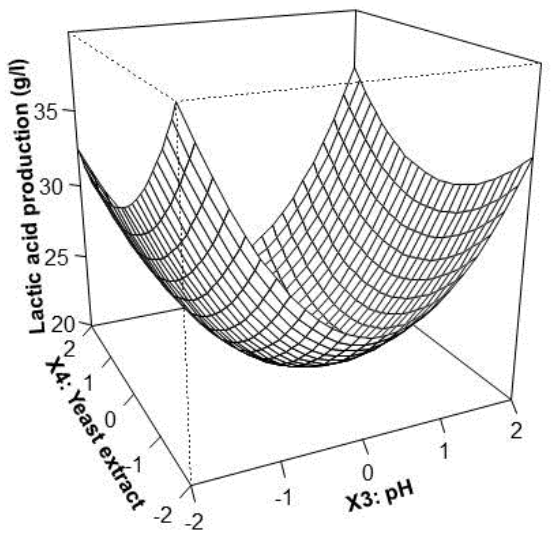

Fig -2: Effects of $\mathrm{pH}$ and yeast extract and their mutual interactions on lactic acid production by Lb. bulgaricus ATCC 11842.

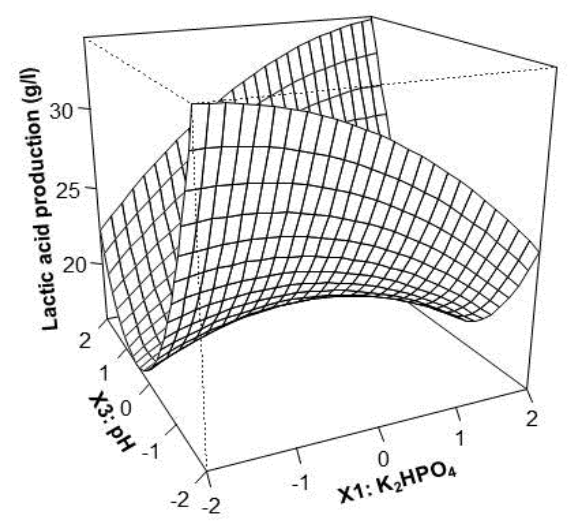

Fig -3: Effects of $\mathrm{K}_{2} \mathrm{HPO}_{4}$ and $\mathrm{pH}$ and their mutual interactions on lactic acid production by Lb. bulgaricus ATCC 11842.

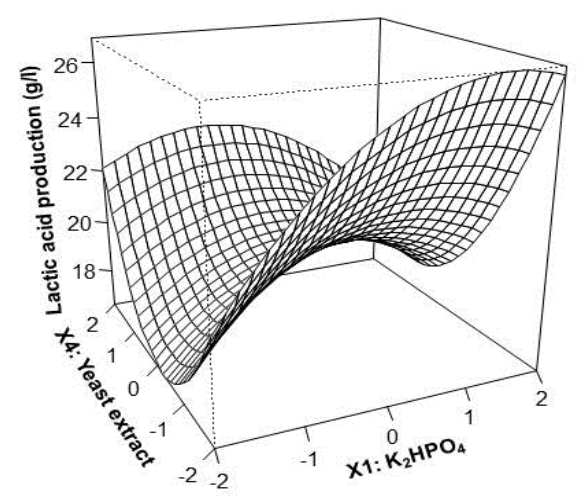

Fig -4: Effects of $\mathrm{K}_{2} \mathrm{HPO}_{4}$ and yeast extract and their mutual interactions on lactic acid production by $L b$. bulgaricus ATCC 11842.

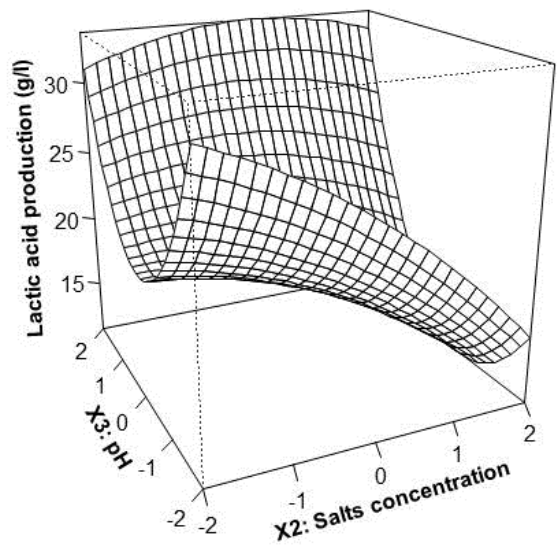

Fig -5: Effects of salts concentration and $\mathrm{pH}$ and their mutual interactions on lactic acid production by $L b$. bulgaricus ATCC 11842.

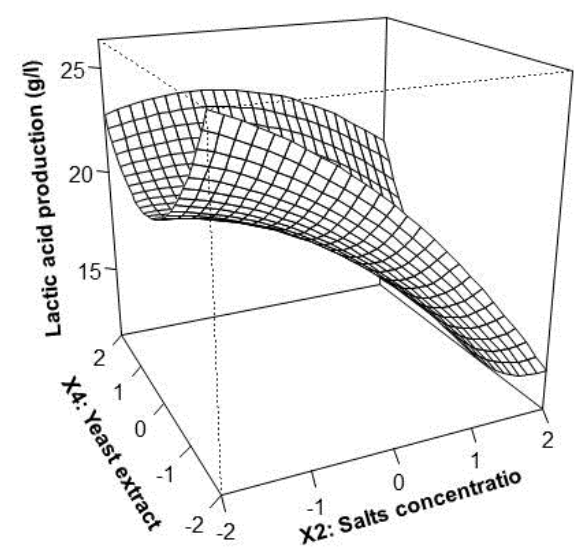

Fig -6: Effects of salts concentration and yeast extract and their mutual interactions on lactic acid production by $L b$. bulgaricus ATCC 11842.

Three replicates of fermentation in Erlenmeyer flasks have been carried out with the optimal results. The results obtained for the three repetitions are in $\mathrm{g} / \mathrm{l}: 19.65,22.52$ and 20.70 with an average of 20.96 .

\section{CONCLUSIONS}

In conclusion, it appears that the response surface method represented here by the composite centered design is very effective in the optimization culture media. Through this method we were able to determine the optima of $\mathrm{pH}$, yeast extract, and sulfates of magnesium, manganese and iron. The optimal production of lactic acid by Lb. bulgaricus (ATCC 11842 ) on deproteinized whey requires $2.713 \mathrm{~g} / \mathrm{l}$ of $\mathrm{K}_{2} \mathrm{HPO}_{4}$, $0.031 \mathrm{~g} / \mathrm{l}$ of $\mathrm{MnSO}_{4}, 0.124 \mathrm{~g} / \mathrm{l}$ of $\mathrm{MgSO}_{4}, 0.012 \mathrm{~g} / \mathrm{l}$ of $\mathrm{FeSO}_{4}$, $1.589 \mathrm{~g} / \mathrm{l}$ of yeast extract and a $\mathrm{pH}$ above 5.5. 


\section{REFERENCES}

[1]. Aeschlimann and Von Stockar U (1990) The effect of yeast extract supplementation on the production of lactic acid from whey permeate by Lactobacillus helveticus. Appl. microbiol. Biotechnol. 432 1: 398402

[2]. Ayroulet-Martin M et Fournaud J (1979) Application de la méthode de LING au dosage de l'acide lactique. An. Technol. agric. $4281,3: 333343$

[3]. Bhushan C, Hiren P, Mayank P, Bharatkumar D (2012) Microbial Production of Lactic Acid by Using Crude Glycerol from Biodiesel. J. Microbiol. Biotech. Res. 2 (1): 90-93.

[4]. Box GEP and Wilson KB (1951) On the experimental attainment of optimal conditions. J. r. Stat. Soc. B13, 1-45

[5]. Calabia BP and Tokiwa Y (2007) Production of d-lactic acid from sugarcane molasses, sugarcane juice and sugar beet juice by Lactobacillus delbrueckii. Biotechnol Lett 29:13291332

[6]. Chiarini L, Mara L and Tabaccbioni S (1992) Influence of growth supplements on lactic acid production in whey ultrafiltrate by Lactobacillus helveticus. Appl. Microbiol. Biotechnol. 36: 461 - 464.

[7]. Cristian J. B. de Lima, Luciana F. Coelho and Jonas Contiero. 2010. The Use of Response Surface Methodology in Optimization of Lactic Acid Production: Focus on Medium Supplementation, Temperature and pH Control. Food Technol. Biotechnol. 48 (2) 175-181.

[8]. Dubois M, Gilles KA, Hamilton JK, Rebers PA. and Smith F. Colorimetric method for determination of sugar and related substances. Anal. Chem. 1956, 4281, 3 : 350356.

[9]. Gonçalves LMD, Barreto MTO, Xavier AMBR. and Klein J (1992) Inert supports for lactic acid fermentation - a technology assessment. Appl. Microbiol. Biotechnol. 38, 305-311.

[10]. Hamamci H, Ryu DY (1994) Production of L(+)lactic acid using immobilized Rhizopus oryzae reactor performance based on kinetic model and simulation. Appl. Biochem. Biotechnol. 44: 125-133.

[11]. Hashitani T, Yano E and Ando Y (2002). Biodegradable Packing Materials for LSIs. FUTJITSU Sci. Technol. J. 38, 112-118.

[12]. Kotzamanidis CH, Roukas T and Skaracis G (2002) Optimization of lactic acid production from beet molasses by Lactobacillus delbrueckii NCIMB 8130. World J. Microbiol. Biotech. 18, 441-448

[13]. Lipinsky ES and Sinclair RG (1986) Is lactic acid a commodity chemical?. Chem. Eng. Prog. 82, 26-32.

[14]. Marques S, Santos JAL, Girio FM, Roseiro JC (2008) Lactic acid production from recycled paper sludge by simultaneous saccharification and fermentation. Biochem. Eng. J. 41 210-216.

[15]. Naveena BJ, Altaf M, Bhadrayya K, Madhavendra SS and Reddy G (2005). Direct fermentation of starch to L (p)lactic acid in SSF by Lactobacillus amylophilus GV6 using wheat bran as support and substrate: medium optimization using RSM. Process Biochem. 40, 681e690.
[16]. Nguyen CM, Kim JS, Hwang HJ, Park MS, Choi GJ, Choi YH, Jang KS and Kim JC (2012) Production of 1-lactic acid from a green microalga, Hydrodictyon reticulum, by Lactobacillus paracasei LA104 isolated from the traditional Korean food, makgeolli. Bioresour Technol. 2012 Apr;110:552-9.

[17]. Plackett RL and Burman JP (1946) The design of optimum multifactorial experiments. Biometrika, 33: 305325.

[18]. Tango MSA and Ghaly AE (1999) Amelioration of lactic acid production from cheese whey using microaeration. Biomass bioenerg. 17, 3: 221 - 238.

[19]. Tashiro Y, Kaneko W, Sun Y, Shibata K, Inokuma K, Zendo T and Sonomoto K (2011) Continuous D-lactic acid production by a novel thermotolerant Lactobacillus delbrueckii subsp. lactis QU 41. Appl Microbiol Biotechnol. 89(6): 1741-50

[20]. Tuli A, Sethi RP, Khana PK and Marwaha SS (1985) Lactic acid production from whey permeate by immobilized Lactobacillus casei. Enz. Microb. Technol. 7 : 164168

[21]. Vishnu C, Seenayya G and Reddy G (2000) Direct fermentation of starch to $1(+)$ lactic acid by amylase producing Lactobacillus amylophilus GV6. Bioprocess Eng 23:155-158 [22]. Xiaodong W, Xuan G and Rakshit SK (1997) Direct fermentative production of lactic acid on cassava and other starch substrates. Biotechnol. Lett. 19(9), 841-843

[23]. Zayed G and Winter J (1995) Batch and Continuous Production of Lactic Acid from Salt Whey using Free and Immobilized Cultures of Lactobacilli. J. Appl. Microbiol. Biotechnol. 44: 362-366. 